\title{
Using prisons to stimulate demographic change: Understanding one community's concerns
}

\author{
Patricia Case $^{1}$
}

This research note summarizes a study that examined county level data to determine the effect of a prison on the growth of the African American population. Does situating a prison in a community result in greater than average minority population growth? While many studies have addressed the effect that a prison siting has on the local economy and the demographics of the prison population, to date there is little research to examine whether or not a prison siting might actually change a community's racial and ethnic makeup. This study was undertaken at the request of a community group that questioned the consequences of this trend to site prisons in predominantly white rural areas. The speculation is that if increased minority residents lead to improved economic outcomes, this will motivate the siting of more prisons and the incarceration of more minorities as a result. [Article copies available for a fee from The Transformative Studies Institute. E-mail address: journal@transformativestudies.org Website: http://www.transformativestudies.org (C2009 by The Transformative Studies Institute. All rights reserved.]

KEYWORDS: Race, Prison Siting, Demographic Change, Institutionalized Racism.

This research note summarizes preliminary findings of a study that was motivated by a concern of a local African American community group. The general impression within this community is that a rural prison siting increases the non-white population within the area and that this increase

\footnotetext{
${ }^{1}$ Dr. Patricia Case is an Assistant Professor at the University of Toledo in Toledo, Ohio. Her research interests include a social psychological understanding of the effects of social trauma on the process related to the development of social identity. She is especially interested in socially marginalized and stigmatized groups. Her work has included studies of the formerly incarcerated, sex workers, and individuals that have dealt with or recovered from near death experiences. Address Correspondence to: Dr. Patricia Case, Department of Sociology, Mail Stop 956, University of Toledo, Toledo, OH 43606; tel: (419) 530-4665; e-mail: patricia.case@utoledo.edu.
} 
is profitable to the predominantly white community while providing no benefit to the non-whites that contribute to this economic growth. Of special concern was that prisons were being used as a deliberate means to make white rural areas eligible for federal funding intended to assist nonwhite communities in development. As the scope of research needed to address the full concerns of the community exceeded funding capabilities, this study focused on one very important part of the equation. Is the community right in its belief that a prison siting will increase the minority population growth in a community beyond the regional averages?

This article briefly summarizes what we know about the effects of prisons on communities and what we know about prison demographics. Also, the conclusions suggest that this is an area of criminological and demographic research that needs to be better understood and outlines potential questions for future research.

Community sentiments are perhaps best summed up by Leo Carroll in his published reaction essay (2004):

They [prison sitings] also unmask the racism that is implicit in the policy to use

prisons as a vehicle for the economic development of impoverished rural areas. Given the geographic distribution of the population by race and racial composition of the prison policy, said policy necessitates that people of color, once again, be forcibly removed from their home communities and relocated in "foreign" territories for the betterment of the largely white population residing there. Once again, we seek to build a rural economy on the backs of black people in bondage.....” (481)

Despite this community belief, to date there is no research designed to explore the relationship between the prison, community demographics and population requirements for federal funding. As the scope of such an investigation would require a large funding source this study was designed to tackle only the first piece of this puzzle: Does the siting of a prison increase a county's minority growth at a rate that exceeds a nonprison county?

\section{PAST RESEARCH}

There is an extensive body of research that examines the relationship between race and prisons. That the African-American community has 
been over-represented in prison populations is well documented in this body of work. Non-whites are more likely to be arrested, charged and later convicted than are whites (Coker, 2003). Racial disparity in incarceration is so pronounced that Petit and Western (2004) argue that incarceration should be viewed as part of the life course for African American males, with $60 \%$ of high school drop-outs within this population spending time in prison at some point in their lives.

The disparity in arrests and convictions for the population has created a conflicted relationship between the criminal justice system and the African American community in the United States. The prison system may be viewed as a 'revolving door' system that is set up to insure that African-American males have little opportunity open to them to avoid incarceration. This 'revolving door' belief is driven by the perceptions of economic advantage from having forced labor from the inmate population (Case and Fasenfest, 2004). This perception is reinforced by the fact that while the disproportional number of African-Americans in prison is well documented, the disparity continues to grow rather than being reversed.

In other words, understanding that there is institutionalized discrimination within the criminal justice process has not created a system of change. In fact, Sorenson (2003) and colleagues found that even when type of crime was taken into account, the disproportional incarceration by arrest remains significant. Furthermore, the recent trend in the war on drugs has increased the likelihood that African-Americans will continue to be over-represented in the prison population. Given the demographics within the prison it is reasonable to expect that the community demographics would also change, however, this is one aspect of prison siting that is not fully understood.

Along with the expected over-representation of minorities, it is widely believed that the siting of a prison will spur economic development in a community (though studies vary in regards to the economic impact of a prison on the local community). The majority of studies that have been undertaken to assess the effect of a prison on a community focus on whether or not a prison is an economic asset to the community (McShane, Williams and Wagoner, 1992). Furthermore, many of the studies that have been undertaken have methodological issues that make it difficult to assess their validity. For example, while Sechrest (1992) reported that a community could expect to see upwards of 700 new jobs following a California prison construction, Richards and colleagues (2004) found that the expense of running prisons in Kentucky contributed to a budget crisis in the state. Despite this crisis, and the 
belief that reducing the prison population would reduce the budgetary drain, the state's prison system had a high rate of parole failure and a continued growth rate in new entries into the system. This continuing drain on budgetary resources associated with the prison clearly demonstrates that prisons are not always profitable.

The economic impact of the prison on a community may depend on the community (Schichor, 1992; McShane, et al 1992). Furthermore, the siting of a prison may be decided more by cheap, available land than by economic need. Marquart (2004) suggests that rather than initiate economic growth (especially in those communities that have recently lost a military base) the prison may serve to slow decline within the community. In fact, many communities that lost a military base in the 1980's competed for the siting of a prison to stave off some of the anticipated economic decline. Hoyman and Weinberg (2006) reported that prison siting is linked to the education of community citizens and the attitudes of the local population and that economic development is not overtly linked to the decision making process.

Also, communities may lack the resources, skills and materials to support the prison once it is built and those who are eventually employed by the prisons often choose to live in other communities (King, Mauer, and Huling, 2004). Finally, low wage jobs within the prison are filled by inmates and therefore there may be no real need for unskilled workers from the surrounding community. This is of special importance since education and job skills tend to be lower in impoverished rural areas.

Despite evidence to support that there may be no real positive economic impact of prison construction in these rural communities, public opinion persists. Hallett (2002) attributes this understanding of prisoners as commodities to the privatization of prisons, in effect creating an environment where "social disorganization [becomes] a market opportunity” (pg 388). Gibbons and Pierce (1995) also found that this perception of economic development and prison siting was the most significant predictor for the decision to site a prison. Cherry and Kunce (2001) found that economic development factors were the primary motivation in the decision to site a prison within a community.

Not all research finds that prisons are less than profitable for a community. Lilly and Deflem (1996) cautioned that ignoring the business side of a prison is a mistake, as there are ties within the prison economy to the military and that these relationships make the punishment of crime a profitable endeavor. 


\section{PUBLIC OPINION AND THE ECONOMY OF DEMOGRAPHICS}

The trend to site new prisons in predominantly white rural counties takes on added importance in a time when prison growth is steadily increasing and efforts are being made at the federal level to set aside funds for targeted underserved populations. Common sense dictates that the demographics in these predominantly white communities would change following the construction of a prison, not only due to the number of non-white inmates that gain residency through their incarceration, but also due to the partners, children and parents who choose to relocate to be nearer their loved ones during the prison term (Krause, 1992). Whether this relocation of families actually occurs has not been adequately addressed, however the belief that it occurs is widespread and does influence community acceptance of a prison siting. Residents indicate that it is these families and prison visitors that generate fear of crime and community problems and not the inmates themselves (Martin, and Myers, 2005; 2004). The white community (especially those in rural areas with little diversity) may view the changing demographics as a negative to the community at large, regardless of any economic benefits.

Clearly, there are opinions within the community about the effect of prison siting on the local community. The African-American community may view the building of a prison as economically beneficial to the predominantly white community due to underserved population requirements for federal funding. In fact, this study was initiated due to the concerns of a local community about the trend to site prisons in predominantly rural areas. The consensus within the community is that counties that can show a healthy percentage of change in black residents may be able to compete for federal monies that are set aside for nonwhite community development. Hence, the county residents on paper drive successful funding, however given that they are incarcerated, they do not benefit from this targeted funding.

Research that addresses the actual effect of prison sitings on community change is sparse and this gap should be addressed. As a result, this study has been designed to start this conversation and to investigate the community concerns by testing the relationship between sitings and minority population growth. Specifically, what effect does the prison's siting in a predominantly white community have on the overall demographics of the county? 


\section{METHODOLOGY}

This study was funded by the Urban Affairs Center at the University of Toledo in response to a community request for data to explore the effect of siting Ohio prisons in predominantly white rural areas. Public opinion in the area held that these rural areas benefited by increasing the minority population and thereby increasing eligibility for federal aid to the county. ${ }^{1}$ Census data was extracted from 1990 and 2000, in order to determine the effect of the prison on county demographics. It was hypothesized that counties which had a prison within their boundaries would have significantly higher rates of minority population growth. Variables taken from the census included population characteristics by race and sex, number of individuals incarcerated and median household income. All variables were recorded at the county level. Several new variables were created as well. First, population change was recorded by subtracting 1990 data from 2000 data. These population variables included change in the total population and black populations, prison growth, and change in the male population. Using the Ohio Department of Corrections database, a dummy variable was created to record whether or not the county had at least one prison within its boundaries $(1=$ prison; $0=$ no prison). ${ }^{2}$ Finally, interaction effect variables were created in order to control for the effect of overall population growth, male population growth and prison population growth. ${ }^{3}$

Variables were analyzed using simple descriptive comparisons and regression analysis to determine the effect of prison occurrence on overall growth in the African American population by county.

\section{RESULTS}

There are 88 counties in Ohio, 21 of which have at least one prison within its boundaries. There are 32 prison facilities in Ohio, five of which are either pre-release centers or medical treatment centers. One prison is for female prisoners only and one is co-ed. African-Americans account for on average $50.5 \%$ of the overall prisoner population within these counties (range 32:8\% - 88.2\%). ${ }^{4}$ 
Table 1. African American Population in Prison Counties

\begin{tabular}{|c|c|c|c|c|c|c|c|}
\hline \multirow[t]{2}{*}{ County } & \multicolumn{2}{|c|}{ Total Population } & \multicolumn{2}{|c|}{$\begin{array}{c}\text { African American } \\
\text { Population }\end{array}$} & \multicolumn{2}{|c|}{$\begin{array}{l}\% \text { African } \\
\text { American }\end{array}$} & \multirow[t]{2}{*}{$\begin{array}{l}\text { Prison } \\
\text { before } \\
\text { 1990* }\end{array}$} \\
\hline & 2000 & 1990 & 2000 & 1990 & 2000 & 1990 & \\
\hline $\begin{array}{l}\text { Allen County, } \\
\text { Ohio } \\
\text { Ashtabula }\end{array}$ & 108,473 & 109,755 & 13,036 & 12,200 & $12.0 \%$ & $11.1 \%$ & $\mathrm{x}$ \\
\hline $\begin{array}{l}\text { County, Ohio } \\
\text { Athens County, }\end{array}$ & 102,728 & 99,821 & 3,020 & 2,896 & $2.9 \%$ & $2.9 \%$ & \\
\hline $\begin{array}{l}\text { Ohio } \\
\text { Belmont County, }\end{array}$ & 62,223 & 59,549 & 1,479 & 1,676 & $2.4 \%$ & $2.8 \%$ & $x$ \\
\hline $\begin{array}{l}\text { Ohio } \\
\text { Cuyahoga }\end{array}$ & 70,226 & 71,074 & 2,424 & 1,191 & $3.5 \%$ & $1.7 \%$ & $x$ \\
\hline $\begin{array}{l}\text { County, Ohio } \\
\text { Fairfield County, }\end{array}$ & $1,393,978$ & $1,412,140$ & 377,424 & 348,208 & $27.1 \%$ & $24.7 \%$ & $x$ \\
\hline $\begin{array}{l}\text { Ohio } \\
\text { Franklin County, }\end{array}$ & 122,759 & 103,461 & 3,166 & 1,148 & $2.6 \%$ & $1.1 \%$ & $x$ \\
\hline $\begin{array}{l}\text { Ohio } \\
\text { Lorain County, }\end{array}$ & $1,068,978$ & 961,437 & 186,999 & 152,166 & $17.5 \%$ & $15.8 \%$ & $x$ \\
\hline $\begin{array}{l}\text { Ohio } \\
\text { Lucas County, }\end{array}$ & 284,664 & 271,126 & 22,837 & 20,625 & $8.0 \%$ & $7.6 \%$ & $x$ \\
\hline $\begin{array}{l}\text { Ohio } \\
\text { Madison County, }\end{array}$ & 455,054 & 462,361 & 75,829 & 67,920 & $16.7 \%$ & $14.7 \%$ & \\
\hline $\begin{array}{l}\text { Ohio } \\
\text { Mahoning }\end{array}$ & 40,213 & 37,068 & 2,383 & 2,830 & $5.9 \%$ & $7.6 \%$ & $x$ \\
\hline $\begin{array}{l}\text { County, Ohio } \\
\text { Marion County, }\end{array}$ & 257,555 & 264,806 & 39,649 & 39,152 & $15.4 \%$ & $14.8 \%$ & \\
\hline $\begin{array}{l}\text { Ohio } \\
\text { Montgomery }\end{array}$ & 66,217 & 64,274 & 3,511 & 2,531 & $5.3 \%$ & $3.9 \%$ & $x$ \\
\hline $\begin{array}{l}\text { County, Ohio } \\
\text { Noble County, }\end{array}$ & 559,062 & 573,809 & 110,779 & 101,390 & $19.8 \%$ & $17.7 \%$ & $x$ \\
\hline $\begin{array}{l}\text { Ohio } \\
\text { Pickaway }\end{array}$ & 14,058 & 11,336 & 781 & 2 & $5.6 \%$ & $0.0 \%$ & \\
\hline $\begin{array}{l}\text { County, Ohio } \\
\text { Pike County, }\end{array}$ & 52,727 & 48,255 & 2,982 & 2,970 & $5.7 \%$ & $6.2 \%$ & $x$ \\
\hline $\begin{array}{l}\text { Ohio } \\
\text { Richland County, }\end{array}$ & 27,695 & 24,249 & 221 & 359 & $0.8 \%$ & $1.5 \%$ & $x$ \\
\hline $\begin{array}{l}\text { Ohio } \\
\text { Ross County, }\end{array}$ & 128,852 & 126,137 & 11,332 & 9,744 & $8.8 \%$ & $7.7 \%$ & \\
\hline $\begin{array}{l}\text { Ohio } \\
\text { Trumbull County, }\end{array}$ & 73,345 & 69,330 & 4,147 & 4,456 & $5.7 \%$ & $6.4 \%$ & $x$ \\
\hline $\begin{array}{l}\text { Ohio } \\
\text { Union County, }\end{array}$ & 225,116 & 227,813 & 17,092 & 15,127 & $7.6 \%$ & $6.6 \%$ & \\
\hline $\begin{array}{l}\text { Ohio } \\
\text { Warren County, }\end{array}$ & 40,909 & 31,969 & 941 & 1,099 & $2.3 \%$ & $3.4 \%$ & $x$ \\
\hline Ohio & 158,383 & 113,909 & 4,303 & 2,401 & $2.7 \%$ & $2.1 \%$ & $x$ \\
\hline
\end{tabular}

* Counties that had at least one prison within its boundaries prior to 1990.

Census data from 2000 reflects an overall population growth of 5\% for the state of Ohio since 1990. In contrast the African-American population grew by 
12\%. Despite this growth in the African American population, the percentage of African-Americans in Ohio remained relatively stable (11\% in 1990 compared to $11.5 \%$ in 2000 ). Counties with at least one prison saw a significantly greater increase in the African American population (187\% compared to 6\% for nonprison counties). ${ }^{5}$ Several prison counties actually had a decrease in African American residency over the decade (See Table 2). A t-test comparison by county showed significant differences in mean change in African American residents for those counties with at least one prison within its boundaries $(\mathrm{t}=$ 3.049; $\mathrm{F}=24.8, \mathrm{p}=.000$ ).

Table 2. Change in African American Population for Prison Counties

\begin{tabular}{|c|c|c|c|c|c|}
\hline County & \multicolumn{2}{|c|}{$\begin{array}{c}\text { Afican American } \\
\text { Population }\end{array}$} & $\begin{array}{c}\% \text { population } \\
\text { Change }\end{array}$ & $\begin{array}{c}\% \text { African } \\
\text { American in } \\
\text { Prisons } \\
\end{array}$ & $\begin{array}{c}\text { Prison } \\
\text { before } \\
1990 \\
\end{array}$ \\
\hline & 2000 & 1990 & & & \\
\hline Allen County & 13,036 & 12,200 & $6.9 \%$ & $44.6 \%$ & $x$ \\
\hline Ashtabula County & 3,020 & 2,896 & $4.3 \%$ & $54.0 \%$ & \\
\hline Athens County & 1,479 & 1,676 & $-11.8 \%$ & $31.7 \%$ & $x$ \\
\hline Belmont County & 2,424 & 1,191 & $103.5 \%$ & $54.4 \%$ & $x$ \\
\hline Cuyahoga County & 377,424 & 348,208 & $8.4 \%$ & $88.2 \%$ & $x$ \\
\hline Fairfield County & 3,166 & 1,148 & $175.8 \%$ & $40.5 \%$ & $x$ \\
\hline Franklin County & 186,999 & 152,166 & $22.9 \%$ & $35.4 \%$ & $x$ \\
\hline Lorain County & 22,837 & 20,625 & $10.7 \%$ & $51.8 \%$ & $x$ \\
\hline Lucas County & 75,829 & 67,920 & $11.6 \%$ & $52.0 \%$ & \\
\hline Madison County & 2,383 & 2,830 & $-15.8 \%$ & $41.3 \%$ & $x$ \\
\hline Mahoning County & 39,649 & 39,152 & $1.3 \%$ & $129.1 \%$ & \\
\hline Marion County & 3,511 & 2,531 & $38.7 \%$ & $44.6 \%$ & $x$ \\
\hline Montgomery County & 110,779 & 101,390 & $9.3 \%$ & $55.6 \%$ & $x$ \\
\hline Noble County* & 781 & 2 & ** & $45.5 \%$ & \\
\hline Pickaway County & 2,982 & 2,970 & $0.4 \%$ & $40.8 \%$ & $x$ \\
\hline Pike County & 221 & 359 & $-38.4 \%$ & $58.8 \%$ & $x$ \\
\hline Richland County & 11,332 & 9,744 & $16.3 \%$ & $55.2 \%$ & \\
\hline Ross County & 4,147 & 4,456 & $-6.9 \%$ & $45.2 \%$ & $x$ \\
\hline Trumbull County & 17,092 & 15,127 & $13.0 \%$ & $56.5 \%$ & \\
\hline Union County & 941 & 1,099 & $-14.4 \%$ & $32.8 \%$ & $x$ \\
\hline Warren County & 4,303 & 2,401 & $79.2 \%$ & $53.5 \%$ & $\mathrm{x}$ \\
\hline
\end{tabular}

* This \% not computed due to the effect of the nearly non-existent non-white population in 1990 and the small county size in general. 
The final analysis of these data was a linear regression. Interaction variables (described above) were used to control for the effect of overall population growth in prison counties and for overall growth in the male population in these counties. (See Table 3). Variables included in this regression were change in the overall population and change in the male population, given that the majority of incarcerated individuals are male. These data suggest that the interaction between prisons and minority population growth within the counties is significant. Including interaction variables in the analysis, did not eliminate the significance of the prison as a variable accounting for growth in African American residents $(\beta=.21 ; \mathrm{t}=-2.983 ; \mathrm{p}=.004)$. Given these results, a county without a prison that has a population growth of 100 and a male population growth of 200 would expect to see an increase of 165 African American residents. These same changes in a prison county would be expected to increase the African American residents by $482 .{ }^{6}$

Table 3. Regression Analysis

Adjusted $\mathrm{R}^{2}: .77$

F: 57.37

Sig: .000

\begin{tabular}{|l|l|l|l|}
\hline \multicolumn{1}{|c|}{ Variable } & \multicolumn{3}{|c|}{ Coefficients } \\
\hline Constant & -451.6 & -1.16 & .25 \\
\hline Prison & -.21 & -2.98 & .004 \\
\hline $\begin{array}{l}\text { Change in } \\
\text { population }\end{array}$ & -6.11 & -6.49 & .000 \\
\hline Change in males & 6.26 & 6.55 & .000 \\
\hline Male interaction & 2.81 & 2.59 & .011 \\
\hline $\begin{array}{l}\text { Population } \\
\text { interaction }\end{array}$ & -2.43 & 2.30 & .024 \\
\hline
\end{tabular}

\section{DISCUSSION}

These data provide evidence that the community is correct in its assumptions that the addition of a prison to a community increases the overall percentage of African American residents within that community. In general, the African American population in the state of Ohio remained relatively stable in the decade between the 1990 and 2000 
census. However, those counties that had prisons saw significantly higher growth in this population. What is less readily tested with existing data is how these changes affect a county's ability to qualify for federal funds that are set aside for under-represented groups. Also, it isn't clear, from either these data or from past research, how much a local economy benefits from the increase in the minority population.

Despite this, a prison appears to be an effective tool for increasing non-white populations in rural areas. For example, one county reported an African-American population of two individuals in 1990 and 781 in 2000. The prison in this county was constructed in 1996. While these data don't provide a causal explanation for the growth in the population, it seems likely that the correlation exists. Approximately $45 \%$ of this prisons population is African American and the change in local demographics may be due to family members moving into the local community to be close to their loved one.

These data are limited in their ability to fully understand the relationship between prisons and minority demographic changes. For example, it isn't clear from these data if counties with prisons also saw growth in manufacturing jobs that confound these results.

Does a prison's construction coincide with the addition of a factory to the local community resulting in demographic change that is not accounted for in this analysis? Also, using only the state of Ohio in this analysis draws conclusions from a very small sample (88 counties; 32 prisons). If this analysis were done at the national level these results might be less pronounced.

Given the understandably conflicted relationship between the African American community and the criminal justice system in the United States, this question should be investigated more fully. For example, the scope of this project did not allow the inclusion of site visits to determine other community changes that might influence demographic change. Also, without a central data base at either the county or the state level for tracking federal funding, it wasn't possible to determine if the prison resulted in increased federal monies to the local community. Furthermore, while the effect of a prison on demographics was significant, the percentage of African-Americans remained stable in these counties overall. It may be that these changes will be more pronounced by the 2030 census. Many of the state's prisons were built after 1980, the most recent being built in 2000. It may be that these demographic changes will be more pronounced as families settle in these areas and stay when the prisoner is released to the community. It is impossible to tell from these data how many of these families are 


\section{Patricia Case}

transient, relocating only for the purpose of providing social support and then returning to their home community post incarceration.

This study therefore provided evidence that prisons significantly effect minority population growth in counties, an important addition to the research body that explores the effect of institutionalized racism in the criminal justice system. Clearly, there are many questions remaining to be explored if we are to truly understand the complexities of this problem. Future research will require significant funding and should take special care to address the economic effect of these demographic changes.

\section{REFERENCES}

Carroll, L. (2004). Prison siting, rural development, racism and justice reinvestment. Criminology and Public Policy, 3(3), 481-488.

Case, P. and Fasenfest, D. (2004). Expectations for opportunities following prison education: A discussion of race and gender. Journal of Correctional Education,55(1), 24-39.

Cherry, T. and Kunce, M. (2001). Do policymakers locate prisons for economic development? Growth and Change, 32, 533-547.

Coker, D. (2003) Addressing the real world of racial injustice in the criminal justice system. The Journal of Criminal Law and Criminology, 93(4), 827-879.

Gibbons, S.G. and Pierce, G.L. (1995). Politics and prison development in a rural area. The Prison Journal 75(3), 380-389.

Hallett, M.A. (2001). Race, crime and for-profit imprisonment: Social disorganization as market opportunity. Punishment and Society, 4(3), 369-393.

King, R.S., Mauer, M., and Huling, T. (2004). An analysis of the economics of prison siting in rural communities. Criminology and Public Policy, 3(3), 453-480.

Krause, J.D. (1992). The effects of prison siting practices on community status arrangements: A framework applied to the siting of California state prisons. Crime and Delinquency, 38(1), 27-55.

Lilly, J.R. and Deflem, M. (1996). Profit and penality: an analysis of the correctionscommercial complex. Crime and Delinquency, 42(1), 3-20.

Martin, R. and Myers, D. (2005). Public response to prison siting: Perceptions of impact on crime and safety. Criminal Justice and Behavior, 32(2), 143-171.

Marquart, J.W. (2004). Economic development is in the eye of the beholder. Criminology and Public Policy, 3(3), 489-492.

McShane, M.D., Williams, F.P., and Wagoner, C.P. (1992). Prison impact studies: some comments on methodological rigor. Crime and Delinquency, 38(1), 105-120.

Myers, D. and Martin, R. (2004). Community member reactions to prison siting: Perception of prison impact on economic factors. Criminal Justice Review, 29(1), 115144.

Petit, B. and Western, B. (2004). Mass imprisonment and the life course: Race and class inequality in U.S. incarceration. American Sociological Review, 69, 151-169.

Richards, S.C., Austin, J. and Jones, R.S. (2004). Kentucky's perpetual prisoner machine: It's about money. Review of Policy Research, 21(1), 93-106.

Sechrest, D.K. (1992). Locating prisons: Open versus closed approaches to siting. Crime and Deliquency 38(1), 88-104. 
Shichor, D. (1992). Myths and realities in prison siting. Crime and Delinquency, 38(1):70-87.

Sorenson, J., Hope, R. and Stemen, D. (2003). Racial disproportionality in prison admissions: Can regional variation be explained by differential arrest rates. Journal of Criminal Justice, 31, 73-84.

\section{ENDNOTES}

${ }^{1}$ Unfortunately, an attempt to collect funding information at the county level in Ohio was unsuccessful. County level information is inconsistent, meaning that not every county has an office or website that is dedicated to tracking funds received by institutions or foundations.

${ }^{2}$ While a few counties had more than one prison within its boundaries, this study did not differentiate between the effects of multiple prisons versus only one prison.

${ }^{3}$ An interaction variable was included to account for the impact of prison growth on the overall male population by multiplying the change in the male population by the dummy variable prison. A similar variable was created using the product of overall population change and the dummy variable prison.

${ }^{4}$ These percentages were computed at the county level and reflect total African American prisoners in county/total prisoners within county. Data were taken from the Ohio Department of Corrections website in August, 2006.

${ }^{5}$ This number reflects two counties that more that doubled the African American residents and one county that went from no residents to nearly 1000.

${ }^{6}$ Estimates include larger growth in the male population due to the demographics of prisons. 